\title{
ANALISIS INFORMASI CITRA MRI GENU POTONGAN AXIAL ANTARA SEQUENCE SHORT TAU INVERSION RECOVERY (STIR) DAN SEQUENCE T2- SPECTRAL ATTENUATION INVERSION RECOVERY (T2-SPAIR)
}

\author{
Suci Ramandasari ${ }^{1}$, Shinta Gunawati ${ }^{2}$, Guntur Winarno ${ }^{3}$, Mahfud Edy W ${ }^{4}$, Fransiscus Heriyanto ${ }^{5}$ \\ ${ }^{1}$ RSUD dr. Chasbullah Abdulmadjid Kota Bekasi \\ ${ }^{2,3,4}$ Poltekkes Kemenkes Jakarta II, Indonesia \\ ${ }^{5}$ RS Mayapada Jakarta \\ Corresponding author: $\underline{\text { Suci Ramndasari }}$ \\ e-mail: suciramanda23@gmail.com
}

\begin{abstract}
Background : This research aims to analyze the information of genu axial section image quality using T2 STIR and SPAIR sequences at Mayapada Hospital.

Methods : The design of this research is quantitative analytics with experimental approaches conducted at the Mayapada Hospital Radiology Installation with the study population taken from all MRI genu examination patients during September-December 2020 with a study sample of 5 patients aged 18-40 years with various complaints on Genu. Then, reconstruction is carried out with a stunt cut techniques on STIR and SPAIR sequence.

Result : The result of this study showed a difference in T2 STIR $d$ an T2 SPAIR with $p$ value of $0.025<0.05$.

Conclusion : The contrast of MRI genu sequence STIR is brighter than SPAIR sequence as evidenced by the calculation of CNR value of STIR sequence 8,388 higher than SPAIR sequence value of 5,345. So it can be concluded that in MRI genu examination, the CNR value on the STIR sequence of a stunt pieces with SPAIR sequence of a stunt pieces has a significant difference.
\end{abstract}

Keyword: Genu MRI, Image Quality, Axial, STIR, T2 SPAIR

\section{Pendahuluan}

MRI (Magnetic Resonance Imaging) merupakan salah satu alat penunjang kesehatan di bidang radiologi yang bersifat non-invasif yaitu dengan memanfaatkan atom hydrogen yang berada di dalam tubuh manusia menggunakan medan magnet, gelombang radio dan komputer untuk menghasilkan irisan anatomi tubuh secara multiplanar dengan kontras resolusi yanga sangat baik. Keunggulan MRI yaitu mencitrakan pembuluh darah, cartilago, bone marrow, jaringan otot, jaringan pengikat, dan jaringan-jaringan lunak tubuh manusia lainnya dengan baik, menjadikan pemeriksaan ini sebagai alternatif terbaik dalam rangka menegakkan diagnosa. ${ }^{13}$ Salah satunya pada pemeriksaan MRI Genu(Brown, Mark A.; Dale, Brian M.; Semelka 2015; Elmaoğlu and Çelik 2012; Kartawiguna, Daniel. 2015).

Genu merupakan sendi engsel yang berfungsi fleksi, ekstensi, serta sedikit fungsi endorotasi dan eksorotasi. Dikarenakan banyaknya fungsi sendi pada genu, maka genu rentan terhadap cedera. Sistem musculoskeletal telah menjadi area yang sangat dikuasai oleh MRI. Sehingga MRI sangat berguna untuk mendiagnosa robeknya ligament cruciate dan collateral serta 
osteonecrosis pada condylus femoris(JACKSON DW,1988; Spouge AR, 2001; Mayahi R, 1986; Lawrence D, 1986; H J, Levy T, 1988).

Lemak sering menjadi sumber masalah pada pemeriksaan MRI genu, karena lemak berada di sekitar struktur anatomi sendi genu. Lemak merupakan komponen molekuler dengan atom hidrogen pada cairan. Maka dalam beberapa kondisi, pemeriksaan MRI genu mengalami kesulitan untuk membedakan lemak dan soft tissue(Gonçalves, S.I. 2011). Untuk mengatasi hambatan tersebut diperlukan teknik yang dapat menampilkan citra jaringan tanpa intervensi dari sinyal jaringan lemak disekitarnya.

Teknik penekanan lemak ini disebut fat suppression (fat-sup). Untuk memperlihatkan kelainan patologis genu digunakan salah satu jenis teknik fat suppressi pada tiap potongan, antara lain Short Tau Inversion Recovery (STIR) atau T2 fat-saturation (fat-sat). Pembobotan patologis (Pathology-Weighting) apabila terjadi proses patologis (lesi atau oedem) maka kelainannya akan tampak terang pada gambar(Gonçalves, S.I. 2011; McRobbie. 2006; Wesbrook C KC.2011).

Short TI Inversion Recovery (STIR) adalah teknik fat suppression yang menggunakan Time Inversion singkat dengan melakukan penerapan pulsa $180^{\circ}$ dan dengan diikuti oleh pulsa eksitasi $90^{\circ}$. Pada penggunaan STIR, kelebihannya adalah dapat digunakan untuk semua medan magnet, penekanan lemak pada semua jaringan, dapat menghasilkan gambaran fat suppression yang homogen pada objek dengan metal implant(Delfaut EM et all,1999).

Spectral Adiabtic Inversion Recovery (SPAIR) adalah metode untuk menekan lemak yang memiliki kelebihan dari suatu penekanan lemak. Teknik ini memiliki karakteristik dengan sensitivitas yang rendah dan ketidak homogennya pulsa $R F$ yang hanya dengan menekan. Sangat sensitif terhadap pengaruh bahan metal(Indrati R.2017).

Untuk evaluasi kualitas gambar, parameter pengukuran kualitas objektif diperlukan agar kualitas gambar dapat dihitung dengan baik sesuai standar algoritma yang telah ditetapkan. Tiga karakteristik yang menentukan kualitas citra yaitu: Signal-tonoise ratio (SNR), Contrast-to-noise ratio (CNR) dan Spatial Resolisi (Westbrook, Roth, and Talbot 2011). Spatial resolution merupakakemampuan untuk membedakan antara dua titik secara terpisah dan jelas, berfungsi untuk melihat ketajaman pada gambar dalam mengidentifikasi obyek yang kecil. SNR yaitu perbandingan antara besarnya amplitudo sinyal dengan amplitudo noise yang mana nilai SNR tersebut digunakan sebagai kriteria untuk menentukan kualitas citra. CNR adalah perbedaan SNR antara organ yang saling berdekatan. CNR yang baik dapat menunjukkan perbedaan daerah yang patologis dan daerah sehat (Arifah, Kartikasari, and Murniati 2017)

Pemeriksaan MRI Genu di Rumah Sakit Mayapada Jakarta Selatan potongan axial mengguakan teknik fat-sup T2 SPAIR, namun pada sequence ini terkadang menghasilkan gambaran citra yang berbeda, sehingga dilakukan penelitian dengan menggunakan sequence lainnya, yaitu T2 STIR untuk menganalisis dan mendapatkan informasi citra gambaran yang optimal dan lebih baik.

\section{Metode}

Jenis penelitian ini adalah penelitian kuantitatif analitik dengan pendekatan eksperimental menggunakan sampel 5 orang dewasa dengan kriteria inklusi usia 18-40 tahun dengan keluhan nyeri pada lutut dan kriteria eksklusi pasien kecelakaan lalu lintas (KLL). Populasi dalam penelitian ini adalah seluruh pasien pemeriksaan MRI geni di Rumah Sakit Mayapada pada bulan september-desember $\quad 2020 \quad$ dengan menggunakan metode sampling purposive sampling.

\section{Hasil dan Pembahasan}

Penelitian ini dilakukan di Instalasi Radiologi Rumah Sakit Mayapada. Pesawat MRI yang digunakan merk Phillips superkonduktor dengan kuat medan magnet 1,5 Tesla dan menggunakan flexi coil.

Sampel yang digunakan berjumlah 5 purposive sampling MRI genu potongan axial sequence STIR dan 5 purposive sampling MRI genu potongan axial sequence SPAIR. 
Data disimpan dalam bentuk DICOM dan dilakukan analisis penghitungan nilai individual pixel dan nilai mean-nya dengan software radiant.

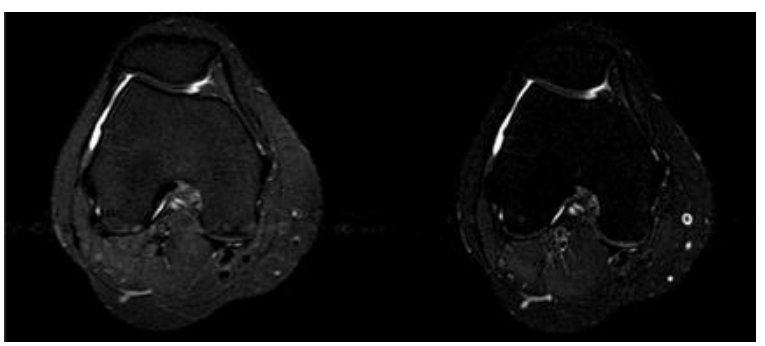

A.

B.

Gambar 1. A. Hasil gambaran MRI Genu potongan axial pada sequence STIR,

B. Hasil gambaran MRI Genu potongan axial pada sequence SPAIR.

\section{Perhitungan secara kuantitatif.}

Penghitungan menggunakan software radiant pada 4 titik, ROI A adalah celah sendi, ROI B adalah cortex, ROI C adalah pembuluh darah dan ROI D adalah softtissue. Dari penghitungan 4 titik ROI dengan software radiant didapatkan nilai mean objek (sinyal) tabel 1, nilai standar deviasi objek(noise) tabel 2 dan standar deviasi background(noise background) tabel 3. Nilai tersebut kemudian digunakan untuk menghitung nilai Signal to Noise Ratio (SNR) dan Contras to Noise Ratio (CNR)

\section{Tabel 1. Nilai Mean Objek}

\begin{tabular}{ccccccccc}
\hline & \multicolumn{4}{c}{ SPAIR } & \multicolumn{5}{c}{ STIR } \\
SAMPEL & \multicolumn{1}{c}{ ROI } & ROI C & ROI & ROI & ROI & ROI & ROI \\
& ROI A & $\begin{array}{c}\text { B } \\
\text { R }\end{array}$ & A & C & D \\
\hline S1 & 246.42 & 71.27 & 169,18 & 160.5 & 491.07 & 307.68 & 581.23 & 523.95 \\
S2 & 229.02 & 120.44 & 103.51 & 140.71 & 808.64 & 407.36 & 615.57 & 516.3 \\
S3 & 536.18 & 170.37 & 323.9 & 270.39 & 589.75 & 324.56 & 203.16 & 361.32 \\
S4 & 192.57 & 190.5 & 133.47 & 171.9 & 515.46 & 424.13 & 463.07 & 519.22 \\
S5 & 504.86 & 320.61 & 164.59 & 231.03 & 562.55 & 339.75 & 549.4 & 577.08 \\
\hline
\end{tabular}

Tabel 2. Noise (standar deviasi)

\begin{tabular}{ccccccccc}
\hline \multicolumn{4}{c}{ SAMPEL } & \multicolumn{4}{c}{ SPAIR } & \multicolumn{4}{c}{ STIR } \\
\cline { 2 - 6 } & \multicolumn{1}{c}{ ROI A ROI B ROI C ROI D ROI A ROI B ROI C ROI D } \\
\hline S1 & 49.89 & 16.16 & 82,81 & 26.32 & 68.4 & 93.76 & 96.56 & 25.35 \\
S2 & 63.63 & 122.97 & 103.63 & 47.26 & 105.18 & 239.06 & 101.44 & 137.16 \\
S3 & 58.98 & 69.65 & 208.71 & 62.38 & 79.45 & 108.18 & 129.76 & 101.13 \\
S4 & 199.95 & 61.02 & 81.38 & 51.71 & 94.42 & 208.14 & 216.76 & 76.76 \\
S5 & 62.48 & 203.58 & 48.62 & 58.73 & 73.54 & 132.15 & 27.75 & 116.33 \\
\hline
\end{tabular}

Tabel 3. Noise Background (Standar Deviasi)

\begin{tabular}{ccccccc}
\hline \multirow{2}{*}{ Background } & \multicolumn{3}{c}{ SPAIR } & \multicolumn{3}{c}{ STIR } \\
& A & B & sd rata & A & B & sd rata2 \\
\hline S1 & 31.24 & 30.93 & 31 & 38.57 & 21.32 & 31.1 \\
S2 & 27.06 & 16.77 & 22.5 & 34.47 & 31.09 & 32.8 \\
S3 & 43.28 & 32.93 & 38.4 & 30.15 & 27,89 & 29 \\
S4 & 40.65 & 33.04 & 37 & 62.52 & 46.33 & 55 \\
S5 & 63.6 & 45 & 77.9 & 49.18 & 29.22 & 40.5 \\
\hline
\end{tabular}

Data mean, standar deviasi objek dan standar deviasi background di buat rata-rata nilai dan dimasukan kedalam rumus pengitungangan untuk mendapatkan nilai SNR dan CNR dapat dilihat pada tabel 4.

$$
\begin{aligned}
\mathrm{SNR} & =\frac{\text { signal } \text { objek }}{\text { noise } \text { objek }} \\
\mathrm{CNR} & =\frac{\text { SNR1-SNR2 }}{\text { noise background }}
\end{aligned}
$$

Tabel 4. Nilai Mean objek, standar deviasi objek, standar deviasi background, SNR dan CNR

\begin{tabular}{|c|c|c|c|c|c|c|c|c|c|}
\hline $\begin{array}{c}\text { Mean } \\
\text { SPAIR } \\
\text { Objek }\end{array}$ & $\begin{array}{c}\text { Mean } \\
\text { STIR } \\
\text { Objek }\end{array}$ & $\begin{array}{c}\text { Sd } \\
\text { Obje } \\
\mathbf{k} \\
\text { Spir }\end{array}$ & $\begin{array}{c}\text { Sd } \\
\text { Objek } \\
\text { STIR }\end{array}$ & $\begin{array}{c}\text { Sd SPAIR } \\
\text { Rata2 } \\
\text { Background }\end{array}$ & $\begin{array}{c}\text { Sd STIR } \\
\text { Rata2 } \\
\text { Backgroun } \\
\text { d }\end{array}$ & $\begin{array}{c}\text { SNR } \\
\text { STIR }\end{array}$ & $\begin{array}{c}\text { SNR } \\
\text { SPAIR }\end{array}$ & $\begin{array}{c}\text { CNR } \\
\text { SPAIR }\end{array}$ & $\begin{array}{c}\text { CNR } \\
\text { STIR }\end{array}$ \\
\hline 159.39 & 475.98 & 30.79 & 62.33 & 31 & 31.1 & 9.28 & 4.372 & 5.65 & 8.795 \\
148.42 & 565.935 & 84.25 & 145.1 & 22.5 & 32.8 & 4.86 & 2.518 & 5.586 & 12.23 \\
325.21 & 384.74 & 99.93 & 104.3 & 38,4 & 29 & 3.89 & 4.355 & 9.526 & 13.33 \\
172.11 & 480.47 & 98.55 & 149.2 & 37 & 55 & 4.099 & 2.262 & 1.597 & 1.728 \\
305.27 & 507.19 & 93.25 & 87.25 & 77,9 & 40.5 & 4.29 & 4.243 & 4.368 & 5.86 \\
\hline
\end{tabular}




\section{a. Uji Normalitas}

Uji ini dilakukan untuk mengetahui apakah data yang diperoleh memiliki distribusi normal atau tidak dan untuk menentukan uji statistik yang tepat.

Tabel 5. Hasil Uji Normalitas SNR

\begin{tabular}{ccc}
\hline Sequence & $p$ value/sig & Makna \\
\hline STIR & 0,005 & $\begin{array}{c}\text { Tidak } \\
\text { Berdistribusi } \\
\text { Normal } \\
\end{array}$ \\
SPAIR & 0,046 & $\begin{array}{c}\text { Tidak } \\
\text { Berdistribusi } \\
\text { Normal }\end{array}$ \\
\hline
\end{tabular}

Berdasarkan tabel 5 diperoleh nilai signifikasi SNR MRI Genu sequence STIR dan sequence SPAIR potongan axial dengan $p$-value sig $<0.05$, sehingga data tersebut tidak berdistribusi normal.

Tabel 6. Hasil Uji Normalitas CNR

\begin{tabular}{ccc}
\hline Sequence & $p$ value/sig & Makna \\
\hline STIR & 0,701 & $\begin{array}{c}\text { Berdistribusi } \\
\text { Normal } \\
\text { SPAIR }\end{array}$ \\
& 0,777 & $\begin{array}{c}\text { Berdistribusi } \\
\text { Normal }\end{array}$ \\
\hline
\end{tabular}

Berdasarkan tabel 6 diperoleh nilai signifikasi CNR MRI Genu sequence STIR dan sequence SPAIR potongan axial dengan $p$-value sig $>0.05$, sehingga dapat disimpulkan bahwa data berdistribusi normal.

\section{b. Uji Statistik}

Uji Paired Sample T-Test adalah pengujian yang digunakan untuk data berdistribusi normal. Uji wilcoxon merupakan uji nonparametris untuk data yang berdistribusi tidak normal.

Hipotesis :

Ho : Tidak ada perbedaan kualitas citra pada MRI Genu pada potongan axial sequence STIR dan T2 SPAIR pada kontras ,detail dan noise.
Ha : Adanya perbedaan kualitas citra pada MRI Genu potongan axial sequence STIR dan T2 SPAIR pada kontras ,detail dan noise.

Kriteria Uji $(\alpha: 5 \%)$ :

Tolak : Ho jika $\mathrm{p}-$ value $<\alpha$

Terima : Ho jika $\mathrm{p}-$ value $>\alpha$

Tabel 7. Uji statistik SNR Paired T-Test Sampel

\begin{tabular}{cc}
\hline Sequence & p value/sig \\
\hline & \\
$\begin{array}{c}\text { SNR SPAIR - SNR } \\
\text { STIR }\end{array}$ & 0,102 \\
\hline
\end{tabular}

Berdasarkan table 7 diperoleh hasil uji statistik yang memiliki $p$ value/sig bernilai $0,102>0.05$ atau lebih dari 0.05 yang artinya Ho diterima. . Sehingga dapat disimpulkan bahwa pada pemeriksaan MRI Genu, nilai CNR pada sequence STIR potongan axial dengan sequence SPAIR potongan axial tidak ada perbedaan yang signifikan.

Tabel 8. Uji statistik Wilcoxon nilai CNR

\begin{tabular}{cc}
\hline Sequence & $p$ value/sig \\
\hline $\begin{array}{c}\text { CNR SPAIR - CNR } \\
\text { STIR }\end{array}$ & 0,025 \\
\hline
\end{tabular}

Berdasarkan tabel 8 diperoleh hasil uji statistik yang memiliki $\mathrm{p}$ value/sig bernilai $0,025<0.05$ atau kurang dari 0.05 yang artinya Ho ditolak. Sehingga dapat disimpulkan bahwa pada pemeriksaan MRI Genu, nilai CNR pada sequence STIR potongan axial dengan sequence SPAIR potongan axial memiliki perbedaan yang signifikan.

\section{Penghitungan secara kualitatif}

Analisa kualitatif dilakukan dengan menggunakan kuisioner yang diberikan kepada 3 orang dokter spesialis radiologi untuk menilai detail anatomi, kontras anatomi dan noise pada area ruang sendi, cortex, pembuluh darah dan soft tissue. 
Tabel 9 Rata-rata Nilai Kuisioner Citra MRI Genu (ruang sendi, cortex, pembuluh darah dan soft tissue) Sequence STIR dan Sequence SPAIR

\begin{tabular}{ccc}
\hline $\begin{array}{c}\text { Penilaian } \\
\text { Informasi Citra }\end{array}$ & STIR & SPAIR \\
\hline Detail Anatomi & $\mathbf{1 1 , 3}$ & $\mathbf{5 , 9 7 5}$ \\
Kontras Anatomi & $\mathbf{1 1 , 6}$ & $\mathbf{7 , 6}$ \\
Noise & $\mathbf{1 0 , 3}$ & $\mathbf{7 , 6}$ \\
\hline
\end{tabular}

\section{Pembahasan}

Berikut adalah pembahasan setelah dilakukan uji statistik menggunakan uji wilcoxon yang didapatkan dari hasil penghitungan ROI pada citra gambaran yang menilai informasi citra yang meliputi (ruang sendi, cortex, pembuluh darah dan soft tissue) pada pemeriksaan MRI Genu sequence STIR potongan axial dengan sequence SPAIR potongan axial.

1. Perbedaan hasil citra MRI Genu sequence STIR potongan axial dengan sequence SPAIR potongan axial berdasarkan hasil analisis software Radiant dan perhitungan statistik didapatkan hasil penghitungan kuantitatif, pada nilai SNR didapatkan nilai $\mathrm{p}$ value/sig bernilai 0,102 . Hal ini menunjukkan bahwa tidak terdapat perbedaan yang signifikan pada nilai SNR citra MRI Genu sequence STIR potongan axial dengan sequences SPAIR potongan axial. Sehingga dapat disimpulkan bahwa pada citra MRI Genu, nilai SNR pada sequence STIR potongan axial dengan sequence SPAIR potongan axial tidak memiliki perbedaan yang signifikan. Hal ini menunjukan intensitas dan detail antara citra MRI Genu sequence STIR potongan axial dengan sequence SPAIR potongan axial tidak jauh berbeda. STIR didasarkan pada perbedaan dalam relaksasi $\mathrm{T} 1$ daripada waktu jaringan tertentu. Waktu relaksasi T1 untuk lemak lebih pendek dari pada air. Saturasi lemak dikhususkan untuk lemak, memberikan rasio signal-to-noise yang lebih baik, dan ini adalah teknik yang dapat diandalkan.

2. Perbedaan yang signifikan terdapat pada CNR pada citra MRI Genu sequence STIR potongan axial dengan sequence SPAIR potongan axial. Pada nilai SNR didapatkan nilai $p$ value/sig bernilai $0,025<0.05$ atau kurang dari 0.05 . Hal ini menunjukkan bahwa terdapat perbedaan yang signifikan pada nilai CNR citra MRI Genu sequence STIR potongan axial dengan sequence SPAIR potongan axial. Sehingga dapat disimpulkan bahwa pada citra MRI Genu, nilai CNR pada sequence STIR potongan axial dengan sequence SPAIR potongan axial memiliki perbedaan yang signifikan. Hal ini menunjukan perbedaan kontras dan noise antara citra MRI Genu sequence STIR potongan axial dengan sequence SPAIR potongan axial. Karena STIR Insensitivity tinggi terhadap Bo inhomogeneity dan memiliki hemogenitas yang baik.

3. Sebagai pembanding juga dilakukan penilaian secara kualitatif dengan menggunakan kuisioner yang diberikan kepada tiga orang responden untuk menentukan nilai detail citra MRI Genu, kontras resolusi citra MRI Genu dan noise rasio citra MRI Genu. Hasil yang didapatkan menunjukkan bahwa Citra MRI Genu sequence STIR potongan axial memiliki detail ruang sendi jelas nilainya 2,33 , cortex jelas nilai nya 2,26, pembuluh darah jelas 2,26 , soft tissue jelas 2,2. Memiliki kontras ruang sendi jelas 2,33 , cortex jelas nilai nya 2,33 , pembuluh darah jelas 2,33, soft tissue jelas 2,33 dan memiliki noise jelas 2,06. Dari hasil wawancara yang telah dilakukan, didapatkan bahwa sequence STIR dalam penekanan lemak pada pemeriksaan MRI Genu lebih baik dari nilai kontras dan noise. Hal ini sesuai dengan keinginan dokter dari hasil wawancara pada pemeriksaan MRI Genu potongan axial. Menurut salah satu dokter di Rumah Sakit Mayapada Jakarta , lebih menyukai sequence STIR daripada sequence SPAIR karena baik untuk melihat marrow odem dan cairan dan memiliki homogenitas yang baik sehingga terlihat batasan gambaran dengan jelas.

\section{Kesimpulan}

Berdasarkan hasil penelitian dengan judul "Analisis Informasi Citra MRI Genu potongan axial antara sequence STIR dan T2 SPAIR di Rumah Sakit Mayapada Jakarta 
Selatan" diperoleh kesimpulan sebagai berikut

1. Terdapat perbedaan yang signifikan pada nilai CNR citra MRI Genu potongan axial dengan sequence SPAIR, nilai $p$ value/sig CNR adalah 0,025 $<0,005$. Perbedaan yang signifikan disebabkan karena nilai kontras gambaran MRI Genu sequence STIR 8.388 lebih tinggi daripada nilai sequence SPAIR 5.345.

2. Tidak terdapat perbedaan yang signifikan pada nilai SNR citra MRI Genu potongan axial dengan sequence SPAIR, nilai $p$ value/sig SNR adalah 0,102>0,05.

3. Berdasarkan hasil wawancara 3 orang responden dokter spesialis radiologi sequence STIR dalam penekanan lemak pada pemeriksaan MRI Genu lebih baik dalam menilai kontras dan noise.

\section{Daftar Pustaka}

Brown, Mark A.; Dale, Brian M.; Semelka, Richard C. 2015. MRI : Basic Principles and Applications. Wiley-Blackwell.

Elmaoğlu, Muhammed, and Azim Çelik. 2012. MRI Handbook MRI Handbook.

Kartawiguna, Daniel. 2015. Tomografi Resonansi Magnetik Inti, Graha Ilmu : Yogyakarta

\section{JACKSON DW, L.D.JENNINGS,} MAYWOOD RM, P.E.BERGER. Magnetic resonance imaging of the knee. 1988;16(1):14-16.

Spouge AR, Pope TL. Practical MRI of the Foot and Ankle. (Spouge AR, Pope TL, eds.). CRC Press; 2001.

Mayahi R, Erturan G, Jackson W, Price A. The Knee: Surface Coil MR Imaging at 1,5 T. Radiology. 1986;159(3):747-751. doi:10.1016/B978-0-323-091381.00077-2

Lawrence D, Kanal E, Brunberg JA, Johnstone GF, Swensen HE, Wolf GL. 1,5 T Surface Coil MRI of the Knee. AJR Am J Roentgenol. 1986;147:293300. doi:0361-803X/86?1472-0293

H J, Levy T, V J. Menisci of the Anterior of the Knee: Cruciate Ligament. Rdiology. 1988;(3):769-774.
Gonçalves, S.I. 2011. Methods for Fat Suppression. University HospitalCoimbra

McRobbie. 2006. MRI From Picture to Proton, Second Edition. Cambridge

Wesbrook C KC. MRI In Practice. united kingdom: blackwell science; 2011.

Delfaut EM, Delfaut EM, Beltran J, Beltran J, Johnson G, Johnson G, et al.

Fat suppression in MR imaging: techniques and pitfalls. Radiographics [Internet].1999;19:373-82.Available from: http://www.ncbi.nlm.nih.gov/pubmed/ 10194785

Indrati R. Comparing SPIR and SPAIR Fat Suppression Techniques in Magnetic Resonance Imaging of Wrist Joint. J Med Sci Clin Res [Internet]. 2017;05(06):23180-5. Available from: Abdulla, Sarah. Clarke, Christopher. 2018. "FRCR Physics Notes."

Arifah, Ahda Nur, Yeti Kartikasari, and Emi Murniati. 2017. "Comparative Analysis of the Value of Signal To Noise Ratio (Snr) At Mri Ankle Joint Examination Using Quad Knee Coil and Flex/Multipurpose Coil." JImeD 3(1): 220-24.

https://www.researchgate.net/publication 1328389266_Analisis_Perbandingan_Nil ai_Signal_to_Noise_Ratio_SNR_pada_P emeriksaan_MRI_Ankle_Joint_dengan_ Menggunakan_Quad_Knee_Coil_dan_Fl exMultipurpose_Coil. 